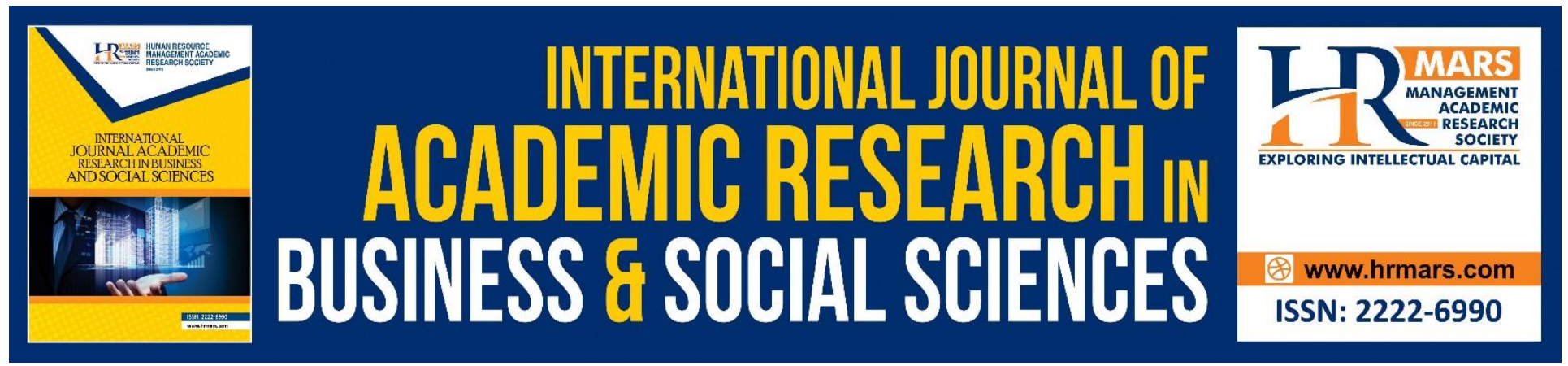

\title{
Tawjih Al-Qira'at Based on Inscription, Language, and Unusual Modes of Recitation According to Ibn Zanjalah
}

Mohamed Fathy Mohamed Abdelgelil, Mohamed Umar al-Janayni, Rohaizan Baru, Mohd. Shafiee Hamzah, Mohd A' Tarahim Mohd Razali, Fatimah Zaharah Ismail

To Link this Article: http://dx.doi.org/10.6007/IJARBSS/v8-i10/4741

DOI: $10.6007 /$ IJARBSS/v8-i10/4741

Received: 18 Sept 2018, Revised: 12 Oct 2018, Accepted: 16 Oct 2018

Published Online: 31 October 2018

In-Text Citation: (Abdelgelil et al., 2018)

To Cite this Article: Abdelgelil, M. F. M., Al-Janayni, M. U., Baru, R., Hamzah, M. S., Razali, M. A. T. M., \& Ismail, F. Z. (2018). Tawjih Al-Qira'at Based on Inscription, Language, and Unusual Modes of Recitation According to Ibn Zanjalah. International Journal of Academic Research in Business and Social Sciences, 8(10), 362-370.

Copyright: (C) 2018 The Author(s)

Published by Human Resource Management Academic Research Society (www.hrmars.com)

This article is published under the Creative Commons Attribution (CC BY 4.0) license. Anyone may reproduce, distribute, translate and create derivative works of this article (for both commercial and non-commercial purposes), subject to full attribution to the original publication and authors. The full terms of this license may be seen at: http://creativecommons.org/licences/by/4.0/legalcode

Vol. 8, No. 10, 2018, Pg. 362 - 370

Full Terms \& Conditions of access and use can be found at http://hrmars.com/index.php/pages/detail/publication-ethics 


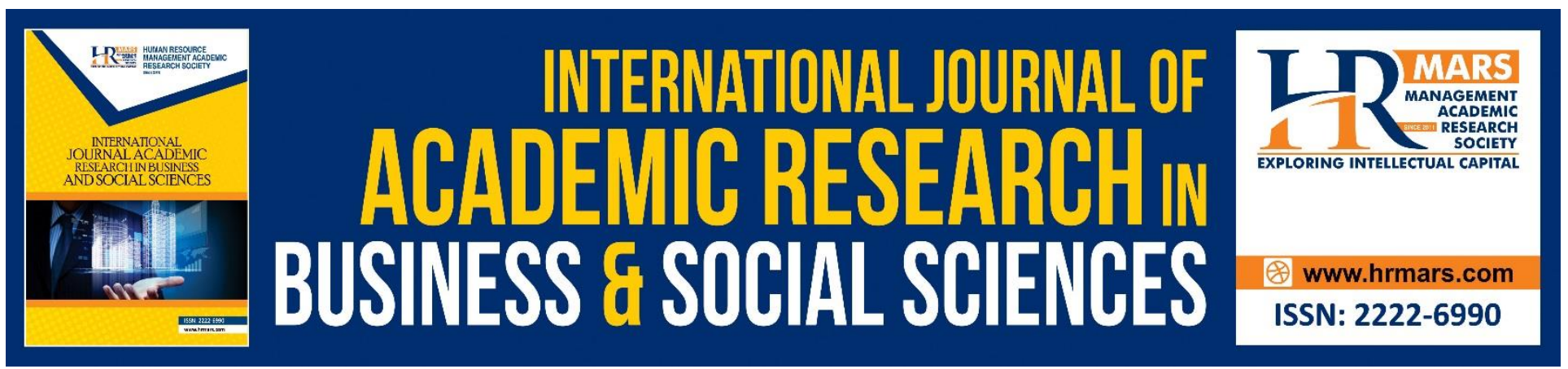

\title{
Tawjih Al-Qira'at Based on Inscription, Language, and Unusual Modes of Recitation According to Ibn Zanjalah
}

\author{
${ }^{1}$ Mohamed Fathy Mohamed Abdelgelil, ${ }^{2}$ Mohamed Umar al-Janayni, \\ ${ }^{1}$ Rohaizan Baru, ${ }^{1}$ Mohd. Shafiee Hamzah, \\ ${ }^{1}$ Mohd A' Tarahim Mohd Razali, ${ }^{1}$ Fatimah Zaharah Ismail \\ ${ }^{1}$ University of Sultan Zainal Abidin (UniSZA), Malaysia \\ ${ }^{2}$ Taif University, Saudi Arab
}

\begin{abstract}
Some people might think that knowledge of Tawjih al-Qira'at (Mode of Quranic Recitation) depends mainly on the science of Quran exegesis and grammar, and some might think that the control is on the language, and might believe that two different modes of recitation are based on tongues. This is really considered a narrow view, and some people may develop curricula based on this perception. Therefore, knowledge of the sciences related to Taujeeh al-Qira'at offers ability for both the teacher and the student to deal with sciences of recitation, which shows the miraculous nature of Quranic recitations. Hence, limited knowledge of one or two related sciences is considered impractical, because Islamic sciences complement one another. This study aims to reveal and evaluate three major issues considered by Ibn Zanjalah in Tawdih al-Qira'at. The study is based on analytical inductive method. Ibn Zanjalah's Hujjat al Qira'at was selected and analyzed based on how the author combined the sciences of illustration, language, and Qira'at al-Shazah (unusual recitations). This study revealed the development of strong interest in the Uthmani inscription in Tawdih al-Qira'at according to Ibn Zanjalah. This was one of the reasons for al-tarjih (preference), as Ibn Zanjalah revealed the languages and dialogues of Arabs, which are considered parts of Tawjih al-Qira'at. However, Ibn Zanjalah's evidences regarding the unusual recitations are insufficient, where there are no more than forty of them. This is considered one of the author's deficiencies.
\end{abstract}

Keywords: Tawjih, Inscription.

\section{INTRODUCTION}

The science of Tawjih al-Qira'at is one of the most important and comprehensive sciences compared to other Islamic sciences. It is based on exegesis, prophetic tradition, as well as regular and unusual 
INTERNATIONAL JOURNAL OF ACADEMIC RESEARCH IN BUSINESS AND SOCIAL SCIENCES Vol. 8, No. 10, Oct. 2018, E-ISSN: 2222-6990 ㄷ 2018 HRMARS

recitations, Quran inscription, grammar, morphology, Arab languages, poetry, and other sciences strengthen it.

Ibn Zanjalah's Hujjah al-Qira'at consists of many exceptional Qur'anic recitations, evidences and references for its validity, which can be justified from numerous directions, such as Qur'an, recitation, prophetic traditions, language and Arabs poetry, grammar and morphology, as well as other things evident in this great work. In general, it is a very useful book in this field, and its author is considered one of the leading scholars in Tawjih al-Qira'at and recitation sciences in general.

Therefore, references are limited to three issues, namely: Tawjih al-Qira'at using inscription, language, and unusual recitations according to Ibn Zanjalah. This paper is limited to the aforementioned issues. On the other hand, this topic is very important and complex, and therefore it might not be possible to analyze all issues of Tawjih al-Qira'at according to Ibn Zanjalah. Hence, narrowing the topic to the above issues is highly significant. Perhaps the Almighty Allah would grant us the ability to author another article that will contain other methods of Tawjih al-Qira'at according to Ibn Zanjalah. This is because the study could serve as a guide for those interested in learning the sciences of Tawjih al-Qira'at or developing curriculum suitable for academic purposes, or for those interested in reading the fundamentals of Islamic sciences in order to develop expertise in the sciences of Tawjih al-Qira'at.

The book is a single volume of 778 pages, and with indexes, the number of pages reaches 814 pages. Its first edition was in 1973 at Mu'assasah al-Risalah, a publishing company in Beirut, Lebanon. The book was checked by Professor Sa id Afghani, and its fifth edition was published in 1997. This study is organized as follows:

- Abstract

- Introduction

- Background of the Study

1. Differences between Tawjih and Hujjah

2. Differences between Qur'an and Recitations

3. Tawjih al-Qira'at in unusual recitations

4. Tawjih al-Qira'at using Qur'an inscription

5. Tawjih al-Qira'at using Arab languages and dialects

- Conclusion

\section{BACKGROUND OF THE STUDY}

The science of Tawjih al-Qira'at is considered one of the sciences that have various names and varied topics, such as recitation errors, recitation phases, recitation control, recitation evidences, recitation analysis, and meanings of recitation. This shows the universality of this field of study and its connection with other Islamic sciences, which would be revealed within the context of this study. 


\section{Differences between Tawjih (Demonstration) and Hujjah (Evidence)}

We often read and hear the terms Tawjih al-Qira'at and Hujjah al-Qira'at. Researches in the field of Qur'an Sciences are familiar these terms because they have been mentioned by some authors, and by mentioning these terms, they mean the science of Tawjih al-Qira'at. Therefore, we will try to highlight the literal and technical meanings of both terms. The term Tawjih is derived from the word wajh (manner), manner of speech, manner of intention. Therefore, it is the root of the word wajjaha. Regarding the technical meaning, Tawjih al-Qira'at means knowledge of the intended meanings of recitations and the approach adopted by each reciter (qari'). However, Hujjah literary means intention, and by extension, the desired intended fact (Manzur, 1414; Faris, 1979).

\section{Differences between Qur'an and Recitations (Qura'at)}

Since there is no need to search for literal meanings, the differences between Qur'an and recitation are directly identified:

Quran: is the word of Allah revealed on to His Messenger Muhammad (peace be upon him). Its recitation is part of worship. Qur'an is written and frequently transmitted. In this sense, it is recognized by its great characteristics and purposes (Ismail, 1999; al-Rumi, 1999).

Recitations: this refers to the pronunciation of words contained in the Noble Quran and how to put the pronunciation into practice, with attribution of every expression to its narrator (al-Ghani, 2005).

It is clear from the above definitions that recitations comprise all words of the Qur'an, irrespective of agreement or disagreement. Nevertheless, Imam al-Zarkashi (may Allah have mercy on him), the author of al-Burhan fi 'Ulum al-Qur'an, is of the view that recitations refer to only the Qur'an words that are disagreed upon. He says "recitations refer to disagreement on the revealed words based on their letters, such as takhfif and tathqil (al-Zarkashi, 1957).

\section{Tawjih Al-Qira'at in unusual recitations}

Islamic scholars dedicated their time to serve the Noble Qur'an and distinguished between authentic and unauthentic narrations and established rules and stipulated conditions for them. Ibn al-Salah acquired the knowledge of unusual recitations while Ibn al-Jazari reported from him and said "the unusual recitations of the Qur'an were transmitted with succession accepted by the Muslim community" (al-Jazari, 1999). Therefore, unusual recitations are beneficial in terms of language and exegesis, and cannot be neglected completely. This is the reason why Ibn Zanjalah relied on unusual recitations in his method of regular recitations in his book Hujjah al-Qira'at, referring to effective language and related chains of transmission. But the reason for its irregularity is its violation of the 'Uthmani inscription. It is recognized by scholars that recitations are accepted based on three conditions: First, its consistency with the rules of Arabic language; second, its consistency with the 'Uthmani inscription; and third, its authenticity in terms of attribution and connection (al-Jazari, 1999). In his book, Ibn Zanjalah has presented a number of unusual recitations as highlighted in the subsequent sections. 
INTERNATIONAL JOURNAL OF ACADEMIC RESEARCH IN BUSINESS AND SOCIAL SCIENCES

Vol. 8, No. 10, Oct. 2018, E-ISSN: 2222-6990 @ 2018 HRMARS

\section{Unusual recitations of Sahabi consistent with the seven recitations}

The recitation of Sahabi is prominent amongst the great companions and consists of recitations inconsistent with 'Uthmani inscription, and the Muslim community reported it as unusual. But sometimes Ibn Zanjalah relates the unusual recitation of Sahabi to the meaning consistent with the regular recitations, as if he tries to strengthen the regular recitation with the unusual recitation. This is evaluated as a moderate approach. At times, Ibn Zanjalah narrates the Sahabi's recitation which is consistent with regular recitation, and he is content with this approach. Therefore, in his recitation and approach, he is able to strengthen the seven narrated recitations. In some instances, Ibn Zanjalah might not be satisfied with the Sahabi's approach, and therefore he adds from other approaches supported by verses from the Noble Qur'an (Zanjalah, 1997).

Ibn Zanjalah reports unusual recitations from one of the companions whose narration is one of the seven modes of recitations, to indicate the testimony of such reciter of the unusual recitation that agrees with and strengthens his recitations. Ibn Zanjalah also mentions the word's origin and the disagreement amongst grammarians regarding the word and its approach (Zanjalah, 1997).

\section{Unusual Modes of Recitation}

Ibn Zanjalah might or might not be satisfied with unusual recitations as a basic evidence for regular modes of recitation. Sometimes his unusual recitation is meant to strengthen the regular recitations, where the meaning in the regular recitation is consistent with that of the unusual recitation. In some cases, he mentions the unusual recitation to strengthen his argument (Zanjalah, 1997).

\section{Reference to Unusual Recitations to Strengthen Argument}

Ibn Zinjal uses an unusual mode of recitation to strengthen a weak argument in Arabic language. He might adopt a new recitation and tries to authenticate it (Zanjalah, 1997). At the end of this section, it will be seen that Ibn Zanjalah referred to a number of unusual recitations in his book Hujjah alQira'at, but these references are limited to 50 recitations only compared to other issues in the book, such as language, poetry, exegesis, grammar, and morphology. In comparison to other books on Tawjih al-Qira'at and language, it is clear that Ibn Zanjalah made significant references to unusual recitations, and this is considered one of the book's limitations, since unusual recitations are considered among the basics of reference by experts of recitation, language and Qur'an exegesis.

\section{Recitation Method Using Qur'an Inscription}

Ibn Zanjalah argued on many recitations in his book Hujjah al-Qira'at with Qur'an inscription. Sometimes, he strengthens or supports his argument by Qur'an inscription. Ibn Zanjalah argued with Qur'an inscription about forty times. Whenever he mentions some recitations narrated in Qur'anic verses, he provides evidences for such recitations from inscription with confidence. It is well known that the evidence is not only strong for him, but also for the entire reciters and experts in recitations, as mentioned earlier that inscription is one of the requisites for the acceptance of recitations. Also, violation of the Qur'an inscription is a strong obstacle to the acceptance of any recitation, and may cause the recitation being categorized as unusual recitation, even if it is valid in terms of transmission and language. In addition, Ibn Zanjalah argues confidently with 'Uthmani inscription, or mentions it 
INTERNATIONAL JOURNAL OF ACADEMIC RESEARCH IN BUSINESS AND SOCIAL SCIENCES Vol. 8, No. 10, Oct. 2018, E-ISSN: 2222-6990 @ 2018 HRMARS

in several guidelines, or strengthens his argument with it. Other related issues would be discussed in the subsequent sections.

\section{The Use of Inscription in Argument or Support for Recitation}

Ibn Zanjalah often makes arguments with 'Uthmani inscription in his book Hujjah al-Qira'at. This shows the extent of its strength and its recognition in recitation science. Therefore, inscription is one of the conditions for any recitation to be accepted (Zanjalah, 1997). Whenever Ibn Zanjalah mentions some recitations narrated in Qur'an verses, he describes their approaches and provides evidence based on inscription. His argument shows the strength of such recitations and its recognition. It is evident that this strength is not only testified by him, but also by the reciters and experts of recitations. Also, violation of the Qur'an inscription is a strong obstacle to the acceptance of any recitation, and may cause the recitation being categorized as unusual recitation, even if it is valid in terms of transmission and language. At times, Ibn Zanjalah does not only provide evidence for recitations with inscription; he begins with inscription and them moves to other methods and vice versa (Zanjalah, 1997). In fact, Ibn Zanjalah used several methods to present his methods of recitations using inscriptions and writing.

\section{Combining Origin and Inscription}

Ibn Zanjalah uses inscription to provide evidences in his book Hujjah al-Qira'at and mentions two sides of the reciter's reading of the word: First, its consistency with inscription and second, its consistency with the word's origin. In most cases, he inclines to recitations with two versions according to the word's origin and 'Uthmani inscription. For instance, Ibn Zanjalah said: Abu 'Umar, Isma il and Warsh recited wa al-badi (والبادي) with ي in the case of al-wasl and hazaf in al-waqaf based on the choice to follow the word's origin. He also said: Abu 'Amru and Warsh recited ka aljawabi (كالجوابي) with in the case of al-wasl and hazaf in the case of al-waqaf according to the word's origin and based on inscription respectively (Zanjalah, 1997).

In the preceding examples, there is a great consideration for inscription, even if it is contrary to the word's origin. However, the reciter combines between the two versions based on the inscription and word's origin. It should be noted that all these are narrated verbally from scholars. On the recitations narrated directly from the Messenger of Allah (peace be upon him), the reciter has no choice on his own.

\section{Ibn Zanjalah's Recognition for Some Recitations Consistent with the Inscription}

Ibn Zanjalah recognizes any recitations that agree with inscription of Mushaf (scripture), as he said: Isma il, Warsh and Abu `Amru recited da'wah al-da'i izha da'ani (دعوة الداعي إذا دعاني) with in the case of al-wasl and without $\mathrm{s}$ in the case of al-waqf. Their reason is that al-ya (ي) is definite because it indicates laam al-fi'l (verb), and it is omitted in the case of al-waqf according to the inscription. This is rational because they followed the word's origin in the case of al-wasl, and in the case of al-waqaf, they followed the inscription (Zanjalah, 1997). 


\section{Connection of Inscriptions with Reciter's Homeland}

Ibn Zanjalah uses inscription to provide evidence for recitations and relate such inscription to the copy of the Qur'an available in reciter's homeland, and not to the reciter himself. For instance, Ibn Zanjalah said that Ibn Kathir read "Allah has prepared for them gardens beneath which rivers flow" (وأعد لهم جنات تجري من تحتها الأنهار) with an addition of the word من (Zanjalah, 1997). His statement means scriptures of the people of Makkah. The following instance is more convincing, as he said: Ibn Kathir read "Moses said, My Lord is more knowing" (قال موسى ربي) without the letter و which is consistent with the scripture of the people of Makkah (Zanjalah, 1997).

\section{Mention of the Reason for Inscription}

Sometimes Ibn Zanjalah mentions the reason for inscription. For instance, he said others read nunajji (ننجي) with double ن which is the future tense of anja (أنجى ينجي), and mu'minun with single ن as an ikhtisar (short form) (Zanjalah, 1997). It can be observed that the reason mentioned by Ibn Zanjalah is ikhtisar.

\section{Mode of Recitations with Arab Languages and Dialects}

Several Arab languages and dialects have been mentioned in Ibn Zanjalah's Hujjah al-Qira'at. Ibn Zanjalah mentioned many of these languages and referred them to various tribes. However, there is a very large number of quotations from the languages without reference, for instance in his statement about two recitations, which is mentioned in Hujjah al-Qira'at about one hundred and thirty-two times. This is a very large number, which indicates Ibn Zanjalah's depth of knowledge in Arab languages and dialects. Nevertheless, this statement is not taken into consideration in this study due to its high frequency. It is only mentioned for the purpose of understanding Ibn Zanjalah's approach to Arab languages and dialects that have been identified, such as the language of $A h l$ Tamim, Qais, and Quraysh, or Ahl Hijaz and Ahl Najd. We do not have to discuss much on this issue, as Ibn Zanjalah does not have a multi-method in his reference. His method is to mention two different recitations or words upon which there is disagreement amongst the reciters. In this situation, Ibn Zanjalah uses the word lughatan which he adopted from others.

\section{Mention of Lughatan without Quotation or Reference to its People}

This is the dominant method used by Ibn Zanjalah. He used to say lughatan in most cases where he provides evidences for recitations using Arab languages, without specifying the language of any people or quoting from others.

\section{Mention of Lughatan with Quotation and without Reference to its People}

Ibn Zanjalah quoted al-Kasa'i, as he said "I have written in all the Mushafs with Sad (ص), al-Kasa'i said 'they are two languages". He also quoted from more than one scholar as he said "al-Kasa'i and Abu 'Ubaydah said "they are two languages". He also said "others read it with al-rafa' and al-Kasa'i and Abu "Ubaydah said they are "two languages". In addition, he quoted without specification where he said "some of our scholars said they are two good languages" or "some people said they are two languages" or "some of the Arab people opined that they are two languages". Then he gives his own opinion and says "they are two new languages used in the recitations" (Zanjalah, 1997). He informs 
INTERNATIONAL JOURNAL OF ACADEMIC RESEARCH IN BUSINESS AND SOCIAL SCIENCES

Vol. 8, No. 10, Oct. 2018, E-ISSN: 2222-6990 @ 2018 HRMARS

the reader that they are two languages, providing evidence with Arabic poem, as he said "note that they are two prominent languages" when the poet said:

$$
\text { ليس من مات فاستراح بميت إنما الميت ميت الأحياء }
$$

(Zanjalah, 1997).

\section{Relating Language to its People}

Ibn Zanjalah mentions lughatan (two languages), and then makes an explanation and reference, as he said "they are two languages", al-takhfif refers to the language of Tameem while al-tathqil refers to the language of the people of Hijaz. At times, he says "two languages", and then quotes others (Zanjalah, 1997).

\section{Languages Mentioned and Recognized by Ibn Zanjilah in his Book}

Ibn Zanjalah mentioned some few languages and paid attention to them in his book. They are as follows: the languages of Bani Hijaz, Bani Tamim, Bani Quraysh, Bani Najd, Bani Asad, Bani Qays and Bani Kinanah.

Ibn Zanjalah paid more attention to the language of Bani Hijaz. He chooses a recitation as long as such recitation refers to the language of Bani Hijaz. He mentioned the reason for paying attention to this particular language more than once; because it is "the language of revelation" (Zanjalah, 1997). But the language of Bani Tamim is cited in about five places (Zanjalah, 1997). The language of Quraysh and that of Ahl Najd are cited twice respectively. Also, the language of Bani Asad and that of Bani Qays are cited once respectively (Zanjalah, 1997).

\section{Reference to Arab Languages}

Ibn Zanjalah mentioned Arabs languages and dialects, citing them to provide evidences for recitations. There are many cases in this regard, including the following:

1. He mentions a word from Qur'anic recitations and says "A language for the Arabs" (Zanjalah, 1997).

2. He mentions that "this word is based on the language of the Arab verbalists" (Zanjalah, 1997).

3. He mentions a word and says "It is a language" or "this is a language" (Zanjalah, 1997).

4. He mentions a Qur'anic word and then proves it as "a famous language" (Zanjalah, 1997, 720).

5. He mentions a language with description, as in his statement "and it is omitted in the case of alwas/ in the best languages, and his statement "Hamzah read li ahlihu munkuthu (امكثوا لأهله) with haa (ه) madmumah and in Surah al-Qasas as well based on the word's origin and specified language (Zanjalah, 1997).

\section{CONCLUSION}

After reviewing Ibn Zanjalah's Hujjah al-Qira'at and reading it several times, this study produced different findings, the most important of which are: 
1. It is evident that Ibn Zanjalah pays much attention to the science of Tawjih al-Qira'at and the disagreement between the sciences contained in his book, such as inscription of Mushaf, as he considered inscription as one of the means through which he analyses recitations.

2. This study revealed Ibn Zanjalah's knowledge of the Arab languages and their dialects, as he considered them as the basics of the science of Tawjih al-Qira'at.

3. Ibn Zanjalah is considered to be the most prominent in quoting unusual recitations, where they reach about 50 different recitations in his book.

The researcher recommends that anyone interested to develop a curriculum in the science of Tawjih al-Qira'at should pay attention to the work of Ibn Zanjalah, and should be careful of the prophetic Hadith or unusual recitations.

\section{Acknowledgement}

Special thanks go to the Research Management, Innovation and Commercialization Centre (RMIC), Universiti Sultan Zainal Abidin.

\section{References}

The Noble Qur'an.

Ismail, M.B. (1999). Dirasat fi 'Ulum al-Qur'an. Cairo: Dar al-Manar.

Al-Jazri, I. (1999). Munjid al-Muqri'in wa Murshid al-Talibin. Beirut: Dar al-Kutub al-'Ilmiyyah.

Al-Rumi, F.A.R. (1999). Dirasat fi 'Ulum al-Qur'an al-Karim. Riyadh: Maktabah Dar al-Muta'allim.

Al-Zarkashi, B.D. (1957). Al-Burhan fi `Ulum al-Qur'an. Cairo: Isa al-Bab al-Halabi \& Co. Press.

Zanjalah, I. (1997). Hujjah al-Qira'at. Beirut: Mission Foundation.

Faris, I. (1979). Mu'jam Maqayis al-Lugah. Beirut: Dar al-Fikr.

Al-Ghani, A.Q. (2005). al-Badur al-Zahirah fi al-Qira'at al-'Ashar al-Mutawatirah min Dariqay alShadibiyyah wa al-Durrah. Cairo: Dar al-Salam.

Manzoor, I. (1414). Lisan al- 'Arab. Beirut: Dar Sadir. 